\title{
THE LIVED EXPERIENCE OF PATIENTS ON MECHANICAL VENTILATION
}

\author{
Portia J Jordan \\ MCur \\ Chief Professional Nurse, Intensive Care Unit, Provincial Hospital, Port Elizabeth
}

\section{Dalena van Rooyen}

DCur

Lecturer, Nursing Science, University of Port Elizabeth

Corresponding author: nsarvr@upe.ac.za

\section{Johanita Strümpher \\ DCur \\ Lecturer, Nursing Science, University of Port Elizabeth}

Keywords: mechanical ventilator; intensive care environment; experiences of patients; physical and emotional stress; accompaniment of patients

\begin{abstract}
Patients connected to a mechanical ventilator have to endure various experiences and emotions, which are unique to each patient. These patients are subjected to physical and emotional stress, which is related to the unfamiliar surroundings of the intensive care environment and the limitations caused by the process of ventilation. Factors that hamper the optimal functioning of patients on the mechanical ventilator include the inability to communicate, the fear of impending dependency and the reality of being faced with their own mortality. The purpose of this study was to identify, explore and describe the experiences of patients who were connected to a mechanical ventilator. A non-probability, purposive sampling method was used. This sampling method was selected because the researcher had to involve patients who were willing and able to communicate their experiences. This was done by means of a conscious selection of patients who had to meet the requirements of sampling criteria set out by the researcher. Data was obtained by means of phenomenological interviews with respondents. Once data was collected, interviews were transcribed verbatim. Data was then analysed according to Tesch's method as described in Creswell (1994:152). An independent coder verified the identified major themes, namely: experiences of patients related to the process of ventilation, as well as their experiences of the environment while connected to the ventilator. A literature control was also done to compare similarities and differences found in data analysis. Ethical principles were maintained throughout the study. The identified experiences formed the basis for the formulation of guidelines to assist the registered nurse in the accompaniment of patients during the ventilation process.
\end{abstract}

\section{OPSOMMING}

Pasiënte wat aan 'n meganiese ventilator gekoppel is, moet verskeie emosies en ervarings deurmaak, wat aan elke persoon uniek is. Hierdie pasiënte word onderwerp aan fisiese en emosionele stres wat verband hou met die onbekende omgewing van die intensiewesorgeenheid, asook die beperkinge wat die proses van ventilasie meebring. Faktore wat op die optimale funksionering van pasiënte inbreuk maak, sluit die volgende in: die onvermoë om effektief met andere te kommunikeer, vrees vir die ontwikkeling van totale afhanklikheid en die realiteit om van hul eie mortalitiet bewus te word. Die doel van hierdie navorsingstudie was om die belewenis van pasiënte wat aan die ventilator gekoppel was, te identifiseer, verken en te beskryf. Data is deur middel van fenomenologiese 
onderhoudvoering met respondente ingesamel. Na insameling van data is onderhoude verbatim getranskribeer. Data-analise is daarna volgens Tesch se metode, soos in Creswell (1994:152) beskryf, uitgevoer. ' $n$ Onafhanklike kodeerder het die geïdentifiseerde hooftemas geverifeer, naamlik: ervarings van pasiënte met betrekking tot die ventilasie proses, asook hulle ervarings van die omgewing terwyl hulle aan die ventilator gekoppel is. ' $n$ Literatuurkontrole is gedoen om ooreenkomste en verskille in data uit te wys. Etiese beginsels is deurgaans in die studie gehandhaaf.

\section{INTRODUCTION AND PROBLEM STATE- MENT}

Mechanical ventilation refers to the movement of air through the respiratory tract into and out of the lungs by means of a ventilator (Weller \& Wells, 1990:492). This implies that a ventilated patient is unable to maintain spontaneous breathing efforts effectively and is dependent on a machine to maintain this vital function. Patients on the mechanical ventilator are subjected to extreme physical and emotional stress in the intensive care unit, for example sleep deprivation, sensory overload, noise as well as feelings of helplessness and isolation.

Dependency on a ventilator continually confronts patients with the fragility of their physical condition and the possibility of permanent disability or death. Patients frequently question if they will ever breathe or function independently again. The prospect of permanent disability threatens their self-image and sense of worth. As they confront disability, they begin the process of redefining their identity and mourning the losses that physical impairment will bring (Belitz, 1983:43). Kotzé (1994:28) supports this statement by stating that the seriously ill person is helpless against his failing body. The condition for his existence now becomes a threat to his existence. The patient's body, which previously granted him independence, now forces him to dependency.

During a conversation with the researcher, one patient verbalised his unique experience as follows: "The experience of being connected to the ventilator was terrible." Patients also verbalised that they felt helpless and frustrated owing to the inability to perform tasks for themselves. Patients on ventilators are often restless and require restraint measures, which contribute to feelings of inadequacy. These examples made the researcher realise that although patients' bodily needs were being met, inadequate attention was being given to their psychological and spiritual needs. Kotzé (1994:29) emphasises that it is important for the body, psyche and spiritual dimension of man to be able to function as a unit. These factors motivated the researcher even more to undertake the study.

Patients who are connected to a mechanical ventilator are unable to communicate effectively with significant others owing to the endotracheal tube placement that obstructs the larynx, thus preventing voice production. This inability to communicate was thus the biggest concern for patients who were connected to the ventilator. It has also been previously documented that patients on a ventilator often experience discomfort and frustration due to their inability to communicate with others. This was intimately related to feelings of anxiety, fear and agony, which created feelings of insecurity while they were on the ventilator. In extreme cases patients can become disorientated, delusional or psychotic (Bergbom-Engberg \& Haljamae, 1993:41).

From experience the researcher noticed that the inability to communicate did produce frustration, apprehension, anger, fear and anxiety in patients on the ventilator. Inability on the part of the nurses to understand their verbal cues, messages and gestures led to the withdrawal and isolation of the patients. Kotzé (1994:35) supports this by stating that factors like defective communication and aphasia due to connection to life-supporting machines contribute to the isolation of the patient.

Patients who are dependent on a mechanical ventilator find themselves immersed in an altered sensory environment. The altered intensive care environment, procedures and routines, as well the feelings produced by the inability to communicate, can cause psychotictype reactions such as paranoia, aggression and hallucinations, which are termed intensive care unit psychosis or intensive care unit (ICU) syndrome. Sensory overload or deprivation and sleep deprivation are also 
contributing factors for the development of this syndrome (Ashurst, 1997:49). Bucher and Melander (1999:554) state that excessive noise, unfamiliar sights, offensive odours, continuous lighting and distorted perception of time are some of the factors that can cause sensory overload. According to Kidd and Wagner (1997:9) sensory deprivation may result from factors such as restricted movements and lack of stimuli such as touch and communication. Patients on mechanical ventilators are constantly exposed to these factors and are thus prone to the development of intensive care unit psychosis.

From experience while working in the intensive care unit, the researcher noticed that patients on a ventilator did have altered senses and thought processes. Patients are confined to the bed, equipment, wires and lines and a ventilator, which limits their physical activities, movement and sight. Because hearing is the primary means of receiving information from their surroundings, patients are constantly exposed to nurses' conversations, noises from various sources, alarms of monitors and ventilators. Perception of time and memory are also distorted, and often patients depend on nurses to orientate them to time and place. Considering all these factors, one could see why being on a mechanical ventilator would bring about a unique experience that only the patient could describe. A patient's ability to cope with this stressful time depends on the nurse's ability to understand these experiences and effectively manage and accompany patients through this period. The researcher believes that this study would not only create self-dependence and self-reliance for patients but also equip the intensive care nurse to manage patients on a mechanical ventilator with greater insight and understanding, especially since patients on the mechanical ventilator accounted for the highest occupancy rate in the intensive care unit.

In the busy world of technology, it is possible to forget the "human being" entrusted to a nurse's care. Therefore the researcher aimed to explore and describe the experiences of patients on a mechanical ventilator. This would ultimately create a greater awareness amongst health care workers for the special needs and demands patients on mechanical ventilators have.
The following questions were posed:

- What is the lived experience of patients connected to a mechanical ventilator?

- What recommendations in the form of accompaniment guidelines can be made to assist the registered nurse to enhance understanding and care of patients on a mechanical ventilator?

\section{RESEARCH OBJECTIVES}

The objectives of the study were:

- To identify, explore and describe the experiences of patients connected to a mechanical ventilator.

- To develop recommendations in the form of accompaniment guidelines for the registered nurse in understanding and caring for patients connected to a mechanical ventilator.

\section{RESEARCH DESIGN}

The proposed study followed a qualitative paradigm that was descriptive, explorative and contextual in nature. Qualitative research is a systematic, interactive and subjective approach used to describe life experience and give meaning to it. The aim of qualitative research is to understand a particular social situation, event, group or interaction (Burns \& Grove, 1997:27). Within the study the researcher attempted to describe the lived experiences of patients connected to a mechanical ventilator. The study explored and described these experiences from the patients' perspective - how they make sense of their experiences and their lives. The study was contextual in that it was conducted in a specific area: the intensive care unit in an urban provincial hospital.

\section{RESEARCH METHOD}

This involves data collection and data analysis and was divided into two phases. During the first phase patients' experiences while they are connected to a mechanical ventilator was explored and described by means of phenomenological interviews. Data was used to identify themes arising from interviews. A literature control followed to place findings within the context of existing literature. In the second phase guidelines was formulated in order to assist the registered nurse in the accompaniment of patients who are connected to a mec-

\section{RESEARCH QUESTIONS}


hanical ventilator.

\section{Population and Sampling}

Non-probability purposive sampling was used. This sampling method was selected because the researcher was required to involve patients who were willing and able to communicate their experiences. This was done by means of a conscious selection of patients who met the requirements of the sampling criteria set out by the researcher. The sample of the study comprised a total of five participants, two males and three females.

The sample criteria stated that participants must:

- be adults (18 years and over); all the participants used in the study were adults ranging in age from 22 to 54 years of age;

- have been connected to a mechanical ventilator for a minimum period of 18 hours; three of the participants in the study were connected to a mechanical ventilator for a period of 20-24 hours, while the other two participants were long-term patients who were on the ventilator for a period of almost two months;

- be English or Afrikaans speaking in order to avoid bias or loss of important information elicited during the process of interpretation; one of the participants in the study was English speaking, while the other four were Afrikaans speaking, thus meeting the sample criteria; and

- be interviewed 12 to 48 hours after discharge from the intensive care unit to ensure a private and relaxing environment conducive to interviewing participants comfortably; interviews were conducted in the general wards within the stated time that participants left the intensive care unit.

\section{Data Collection}

Data was collected by means of unstructured phenomenological interviews. The following question was posed to the patients: "How would you describe your experience while connected to the ventilator?"Unstructured interviews are considered the most effective way of gaining an understanding of people's perceptions. The unstructured interview does not use an interview schedule that contains a common set of standardised questions but rather allows the interview to be exploratory in nature. In an unstructured interview the researcher can adapt, develop and generate questions appropriate to a given situation and the central purpose of the study (Tutty, Rothery \& Grinnel, 1996:56). In order to obtain an in-depth, dense description and understanding of the patients' world while they were connected to the mechanical ventilator, it was therefore decided to utilise an unstructured interview.

A phenomenological approach was used since it enabled the researcher to gain a deeper understanding of the lived experiences of patients connected to a mechanical ventilator. Phenomenology is a philosophy and a research approach that focuses on the meaning of lived experiences. The intention of using a phenomenological approach is to examine and describe the phenomena as they appear in the lived experiences of the individual (Morse \& Field, 1996:199). The individuals must, however, have experienced the phenomenon being explored and must be able to describe their conscious experiences.

The researcher used an audiotape recorder to tape the interviews, which were then transcribed verbatim. A personal journal and field notes were also used to record the researcher's own feelings, reactions and observations. Data was saturated as evident in the repetition of themes.

\section{Data Analysis}

Data analysis was done according to Tesch's method as described in Creswell (1994:155). An independent coder was used to assist in identifying themes related to the patient's experiences on the ventilator. Within the scope of identified themes, consensus was reached with the independent coder in order to ensure that data was saturated and that no more interviews needed to be conducted.

A literature control was done to verify whether the identified themes had been previously documented. It was also conducted in order to compare findings and determine similarities and/or differences in existing data in literature. 


\section{TRUSTWORTHINESS}

Guba's model of trustworthiness as described in Krefting (1991:215-222) was used to ensure trustworthiness. Guba's model is based on the identifica- tion of four aspects of trustworthiness, namely truthvalue, applicability, consistency and neutrality, which were applied to the research study (see table 1).

\section{Table 1: Strategies to ensure trustworthiness}

\begin{tabular}{|c|c|c|c|}
\hline THEME & STRATEGY & CRITERIA & APPLICATION \\
\hline \multirow[t]{5}{*}{ Truth Value } & Credibility & $\begin{array}{l}\text { Prolonged and } \\
\text { varied field } \\
\text { experience }\end{array}$ & $\begin{array}{l}\text { The researcher's previous exposure } \\
\text { to patients on mechanical ventilators. }\end{array}$ \\
\hline & & Reflexivity & $\begin{array}{l}\text { The researcher will use a field journal } \\
\text { and personal diary for recording of } \\
\text { thoughts and feelings. }\end{array}$ \\
\hline & & Member checking & $\begin{array}{l}\text { Continual checking with informants to } \\
\text { verify data will be done. }\end{array}$ \\
\hline & & Peer examination & $\begin{array}{l}\text { Researcher will discuss findings with } \\
\text { colleagues. }\end{array}$ \\
\hline & & $\begin{array}{l}\text { Structural } \\
\text { coherence }\end{array}$ & $\begin{array}{l}\text { The experiences of informants will be } \\
\text { described. Results would be } \\
\text { integrated and reflected within the } \\
\text { Nursing Theory of Accompaniment. }\end{array}$ \\
\hline Applicability & Transferability & Nominated Sample & $\begin{array}{l}\text { Sampling will be purposive, non- } \\
\text { probable and criterion-based. }\end{array}$ \\
\hline \multirow[t]{2}{*}{ Consistency } & Dependability & Dependability Audit & $\begin{array}{l}\text { A personal journal and field notes will } \\
\text { be used. }\end{array}$ \\
\hline & & $\begin{array}{l}\text { Code-record } \\
\text { procedure }\end{array}$ & $\begin{array}{l}\text { Consensus discussions between } \\
\text { researcher and independent coder } \\
\text { will be held to discuss identified } \\
\text { themes. }\end{array}$ \\
\hline Neutrality & Confirmability & Audit & $\begin{array}{l}\text { The research report will be } \\
\text { sufficiently detailed for a secondary } \\
\text { researcher by using the original data } \\
\text { to arrive at similar conclusions. }\end{array}$ \\
\hline & $\begin{array}{l}\text { Triangulation } \\
\text { of data } \\
\text { methods and } \\
\text { data sources }\end{array}$ & & $\begin{array}{l}\text { An experienced qualitative } \\
\text { researcher will supervise. Literature } \\
\text { control will be completed using } \\
\text { journals, articles and internet searches. }\end{array}$ \\
\hline
\end{tabular}




\section{ETHICAL CONSIDERATIONS}

Ethical principles were maintained throughout the study in order to protect the patients/participants from harm or risk. The principles as set out in the Ethical Standards for Nurse Researchers (South African Society for Nursing Researchers, 1996:74-75) were adhered to. These principles include: confidentiality and anonymity, privacy, consent, release or publication of findings and restoration of participants in the form of debriefing sessions where necessary.

\section{DISCUSSION OF RESULTS}

Two major themes were identified namely:

- The experiences of patients related to the process of ventilation itself;

- Their experiences of the environment while connected to the mechanical ventilator.

Sub-themes related to these major themes will also be discussed (see table 2).

Table 2: Identified themes related to the lived experience of patients on a mechanical ventilator

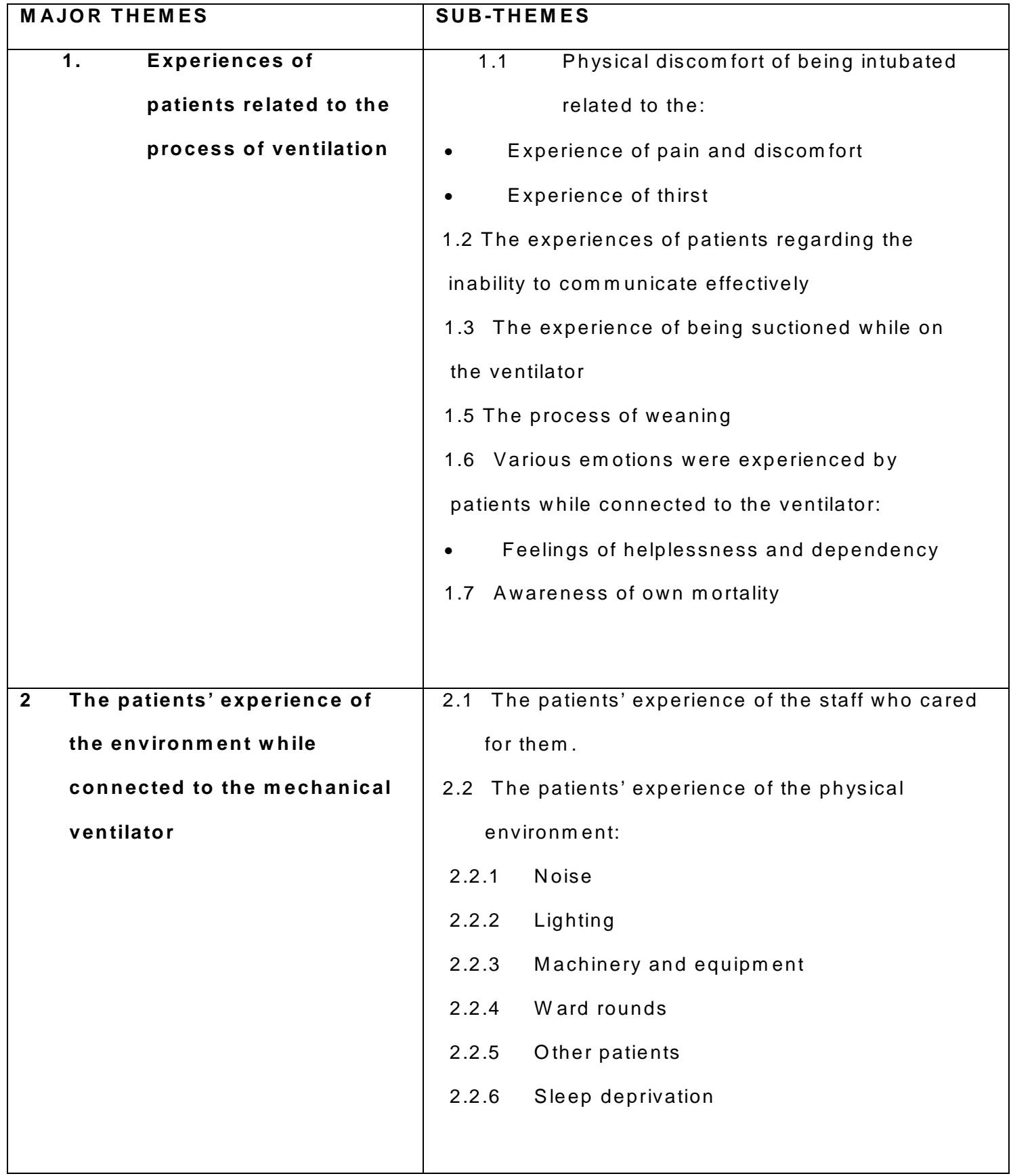




\section{THEME 1: EXPERIENCES OF PATIENTS RELATED TO THE PROCESS OF VENTI- LATION}

\section{Physical discomfort of being intubated}

Some patients stated that the process of being intubated was more uncomfortable than painful. Others, however, reported that the strapping used to secure the endotracheal tube was more painful than the tube, which was situated in the nose or mouth. Patients also reported that they had experienced pain, especially a sore throat, after they had been removed from the mechanical ventilator. The sore throat was not permanent though and seemed to disappear within a few days after extubation.

"Dit was ongemaklik veral omdat dit teen my neus gedruk het en die 'strapping' het ook ietwat seergemaak." (It was uncomfortable especially since the tube pressed against my nose - the strapping also hurt me). "It was terrible when the pipe came out the next morning. That was now sore, really."

Johnson and Sexton (1990:48) supported this subtheme in their exploratory study conducted regarding the factors that were distressing for the patient during mechanical ventilation. They suggested that a major source of distress for patients on the mechanical ventilator was pain and discomfort caused by the presence and necessary care of the endotracheal tube.

\section{Thirst}

According to data, thirst was a problem experienced by patients on the ventilator, which contributed to the frustration they experienced. The frustration was as a result of not being informed why water was not permissible while they were on the ventilator. Had the nurse provided the patient with the necessary explanations and information regarding the problem of thirst and why they could not drink anything while connected to the ventilator, these feelings of frustration may have been reduced. One patient expressed his frustration as follows: "Dit was frustrerend want ek was dors en wou tog net bietjie water hê - maar ek kon niks drink op die masjien nie en ek het gevoel dat dit tog seker nie te veel gevra is nie." (It was frustrating because I was so thirsty and I only wanted some water but I could not drink anything while on the machine. I felt that was not too much to ask).

\section{Inability to communicate}

Verbal communication is impaired for the patient on a ventilator, owing to the endotracheal tube placement, which obstructs the larynx and voice production. This inability to express needs to significant others produced feelings of anxiety, fear, stress, agony, frustration and isolation for the patients on the ventilator. Patients felt especially frustrated when they required something urgently, e.g. water, and nobody was able to understand them. This communication impairment resulted in patients feeling powerless, inadequate and alone and caused them to withdraw from others in their environment. When they were extubated, they were relieved and the ability to express their needs verbally made them feel more in control of themselves and their surroundings.

The patient's inability to express him/herself verbally also made him/her feel that he/she had to find alternative modes of communication in order to convey his/ her needs. It was noted that despair and frustration often forced patients to use non-verbal modes of communication including gestures, incomprehensible sounds to attract attention and expression through writing. Patients also felt that nurses were sometimes too busy to spend sufficient time attempting to understand their modes of communication. They perceived this inability to be understood as a factor causing stress and frustration for the nurse. Other patients felt that the inability to be understood prevented the nurse from providing adequately for their needs.

The above statements are supported by the following quotes as expressed by patients:

"I was left to the mercy of others. I remember that I tried to draw attention by trying to make a noise with my tongue in my cheek and that worked." "Ek het eintlik verwag dat die suster van beter sou geweet het, veral omdat sy elke dag met die tipe pasiënte werk ... hoe meer ek probeer verduidelik het, hoe meer het gelyk 
sy vererg en frustreer haar." (I actually expected that the sister would know better, especially since she nurses these types of patients every day ... the more I tried to explain, the more she appeared to be irritated and frustrated).

An extensive literature control revealed that impaired communication for patients on a mechanical ventilator produced various feelings of anxiety, fear, agony and panic. Corbo (1995:41) stated that $86 \%$ of the patients in their study on adolescent ICU experiences tried or wanted to talk while they were on the ventilator and to them it was a frustrating experience.

\section{Suctioning}

Patients experienced the suctioning procedure differently. Some reported that the procedure was helpful and provided relief in the sense that it made their breathing easier after the secretions had been removed while others said that it produced pain and discomfort and that they would rather not have had it. For some patients the process of suctioning appears to have been a terrible experience and was linked to feelings of suffocation and was stated as follows: "Dit het gevoel hulle suig my longe uit en alles trek saam as hulle die suigkateter uittrek. Later toe ek baie slym gehad het, het dit gehelp om van die slym ontslae te raak, as die slym min was, was dit erg en by tye het dit gevoel ek 'suffocate'." (I felt as if they were pulling my lungs out with the suction catheter. Later when I had a lot of mucus, it helped to get rid of the mucus, but when there was a little mucus it was terrible and at times I felt as if I was suffocating).

These different experiences may be related to the different techniques used by different nurses when performing suctioning. Turner, Briggs, Springhorn and Potgieter (1990:968) supported this in their study on patients' recollections of the intensive care unit experience stating that suctioning was reported to be unpleasant and some patients reported that certain nurses made suctioning easier to tolerate than others.

\section{The process of weaning}

During the weaning process patients experienced a sense of being dependent on the ventilator, which pro- duced tremendous fear for these patients. Stress, fear and anxiety related to the process of gradually beginning to breathe on their own and being less dependent on the ventilator for support was a reality for these patients and they felt they would not be able to breathe on their own once the machine was removed.

The fear of future dependency on the ventilator was a recurrent concern that patients expressed as follows: "I was anxious and frightened because I thought now once the machine is off l'm not going to make it on my own." They feared that they would never be able to function as normal human beings again and that they would be dependent on the ventilator for the rest of their lives. Knebel (1991:325) supports this in her article on weaning from mechanical ventilation by stating that anxiety and fear are often due to dependency as well as the prospect of permanent disability (inability to breathe without the ventilator support), fear of death and the inability to communicate their needs.

Although the weaning process produced feelings of dependency and fear, patients also realised that these feelings were short-lived once they began synchronising their breathing with that of the machine. It gave them a sense of gaining more independence and selfcontrol. Patients also felt uncertain regarding the weaning process and their ability to breathe unaided again. This was illustrated when one patient verbalised the following: "Toe hulle die masjien afgehaal het, het ek gedink nou sal ek nie op my eie kon asemhaal en ek was bang om selfs in die nag te slaap." (When they removed the machine I thought that I would not be able to breathe on my own and I was even afraid to sleep at night). This uncertainty could be as a result of not being informed or reassured about the process of weaning. This made the researcher realise that accompaniment throughout the weaning process was important for patients on a ventilator. No literature could be found to support this identified theme.

\section{Helplessness and Dependency}

The movement of patients on the ventilator is usually restricted by the various pieces of equipment such as 
the ventilator, tubes or line essential for recovery. These restrictions made patients feel even more dependent on others, especially nurses, to perform/meet their daily activities/requirements. Dependency was not only limited to physical activities, but also stretched to all aspects of care. The nurse has the power to decide when the patient is washed, when he/she receives meals/is fed and when he/she is allowed to have visitors. Patients felt that they had no say in the matter due to their dependence on the nurses to meet their basic needs. "Ek het hulpeloos en mismoedig gevoel omdat ek niks vir myself kon doen en moes op ander mense staatmaak om selfs my mond skoon te maak." (I felt helpless and miserable especially since I could not do anything for myself and had to rely on others even to clean my mouth). Dependency produced feelings of hopelessness and impaired self-worth in these patients. Belitz (1983:43) states that dependency on a ventilator continually confronts patients with the fragility of their physical condition and the possibility of permanent disability or death, which threatens their self-image and sense of worth.

\section{Awareness of own mortality}

Patients reported an awareness of their own mortality while on the ventilator, they realised that their survival depended on God's grace alone and viewed prayer as an important component in overcoming the disease process and the intensive care environment. "The whole time I just prayed that it must be over soon that I could make it and not die." Patients also perceived being confronted with death in a spiritual sense. It seemed as if they experienced a closer and deeper relationship with God and gratitude towards God was especially prominent. The feeling of the near-death experience also made patients view the ventilator as an aid contributing to their healing and ultimately helping them to recover successfully. 'My 'experience' op die ventilator was 'positive' in die 'sense' dat dit bygedra het tot my beterskap." (My experience on the ventilator was positive in the sense that it contributed towards me getting better).

According to Jablonski (1994:205) patients on the ventilator experience a vast range of emotions as they attempt to come to terms with their ventilator dependency and their disease process. These feelings include the near-death experience. No other literature could be found to support this experienced awareness of a patient's own mortality while on the mechanical ventilator or while critically ill.

\section{THEME 2: PATIENTS' EXPERIENCES OF THE ENVIRONMENT WHILE ON THE ME- CHANICAL VENTILATOR}

\section{Patients' experience of the staff who cared for them}

From the data obtained, it was evident that patients in the study found the general nursing care rendered to be caring and supportive. They felt that nurses reassured them by giving adequate explanations regarding procedures and care. "Nadat die suster vir my gesê het wat fout was, was ek 'OK' en die alarms het my toe nie meer gepla." (After the sister had told me what was wrong, I was OK and the alarms did not bother me anymore). Patients also reported that nurses responded timeously to circumstances like alarms going off. Patients also felt that nurses involved them in self-care activities. One reported factor of dissatisfaction was the nurses' inability to understand their mode of communication in order to maintain effective twoway communication. They also felt that nurses could improve on their communication techniques, especially when rendering care to patients on a ventilator. "I felt that it prevented them from knowing what I wanted and it did prevent them from providing for all my needs." In a study done by Jablonski (1994:205) it was reported that the inability to communicate with patients did impinge on the quality of care rendered to patients on the mechanical ventilator.

\section{The patients' experiences of the physi- cal environment}

\section{Noise}

Patients reported that noise levels were very disturbing in the intensive care unit, and greatly affected their emotional state and sleep patterns. The ventilator alarms, alarms of the infusion sets, other patients and staff were especially disturbing. "Dit is daai geluid van die alarms wat nou nog in my gedagtes afspeel, soms wou ek net my ore en oë toemaak om daarvan te 
vergeet." (The sound of the alarms continually plays off in my mind; sometimes I wanted to close my ears and eyes in order to forget about it). In a study done by Johnson and Sexton (1990:50) it was found that more than $50 \%$ of participants reported noise as being very distressing and all indicated that they were bothered by noise from other patients.

\section{Lighting}

Continuous, bright lighting, especially during the night, was disturbing for the patients and it affected their sleep patterns to a great extent. "Die groot ding was die ligte, ek kon nie slaap met die ligte wat heel nag brand." (The main thing were the lights, I could not sleep with the lights on throughout the night). They also reported that it affected their sense of differentiating between day and night and made them feel disorientated in terms of time, place and people. Jones, Griffiths, Macmillian and Palmer (1994:48) support this when stating in their article that harsh lighting as well as inadequate lighting, often leads to patient disorientation.

\section{Machinery and equipment}

This includes the ventilator, monitoring system, intravenous infusion lines, underwater drainage bottles and tubes, and other essential equipment. It was interesting to note that patients felt anxious when waking up and becoming aware of all the equipment and machinery. "I did not remember anything about the operation, but when I woke up and saw the bunch of lines and heard the breathing machine and saw it, I became anxious." However, it was more the unexpected sight of all the machinery that indicated how important prior psychological preparation, where possible, is for these patients. According to a qualitative study done by Raleigh, Lepczyk and Rowley (1990:941) on the benefit of pre-operative information, pre-operative instruction is beneficial for patients because it reduces patient anxiety and aids in recovery. Nurses should therefore assist patients in strengthening their resources through pre-operative instruction and education.

\section{Ward rounds}

Patients specifically remembered ward rounds done by doctors discussing their progress or treatment. An interesting observation was that the long-term patients felt that doctors should not assess them every morning, especially if they are not progressing as it makes them depressed and miserable. "Later het ek mismoedig geword en gewens die dokters vertel my nie meer wat aangaan." (Later I became despondent and wished that doctors would rather not inform me). One thus has to seek an alternative for the bedside ward rounds for these patients. No data could be found to support this identified sub-theme.

\section{Other patients}

Other patients were especially disturbing for patients in the intensive care unit, and they perceived their presence as a contributing stressor for them. Patients perceived themselves through the eyes of others and often questioned their own mortality and recovery. "The one opposite me was very sick - I thought I am going to become like him and that I would never leave the ICU."

\section{Sleep deprivation}

Patients felt that their sleep was constantly interrupted and that noise-induced sleep deprivation was one of the most disturbing factors. Some patients also said that sleep deprivation caused them to feel anxious, delusional and suspicious. They felt that nurses should be more sensitive to their sleeping needs. "Hier in die saal is daar nie so baie siek mense. Daar in 'ICU' bly die mense besig en dit vroetel en raas ... dit is hoekom ek nie kon slaap nie ... het nagte wakker gelê." (Here in the ward there are not so many sick people. In ICU they are continually busy and noisy... that is why I could not sleep... lay awake most of the time).

Topt and Davis (1993:252) state in a study done on critical care unit noise related to rapid eye movement that noise is one of the greatest factors contributing to impaired sleeping patterns, which may contribute to serious negative psychological outcomes such as intensive care psychosis. It is therefore important that patients in the intensive care unit have adequate sleep. 


\section{GUIDELINES}

Guidelines are orientated towards the accompaniment of patients while connected to the ventilator. These guidelines were formulated in relation to the Nursing Accompaniment Theory of Kotzé (1998:3-14).

Based on the insight gained through the findings of the study and the patients on mechanical ventilation, the following are offered as accompaniment guidelines.

\section{Improving physical comfort}

Improving the current method of securing the endotracheal tube with strapping without causing pain as is currently experienced by patients

Endotracheal tubes should be secured in such a way that complications such as accidental extubation, tube displacement, ulceration of lips or mouth and facial skin trauma are prevented. The researcher suggested and implemented various methods to secure the tube in order to find the best possible way to minimise pain and discomfort for the patient on the ventilator. These methods were also discussed with the respiratory technician in order to get an expert's opinion.

\section{Relieving the experience of thirst in pa- tients on the ventilator}

Staff must be taught methods to alleviate the patient's feelings of thirst while connected to the ventilator. Inservice training programmes can introduce a protocol, which includes nursing interventions to reduce feelings of thirst and dry mouth. Thirst can be relieved with small sips of water or by sucking ice chips or on a moistened sponge. Dryness of the mouth can be relieved by increasing salivation through chewing sugarless gum, sucking on hard candies or lozenges or providing artificial saliva substitutes.

\section{Improving suctioning techniques}

Intolerance of the suctioning procedure may be reduced in the following ways:

- Explaining to the patient that the suctioning is aimed at reducing discomfort.

- Ensuring hyperinflation and adequate preoxygenation before and after each suctioning in order to minimise the breathless, choking feeling.

- Using an assistant to assist with hyperinflation and chest vibration during suctioning in order to achieve quick and effective removal of secretions.

\section{Reducing the incidence of sleep depriva- tion}

Intensive care nurses should be more aware of sleep disturbances and should implement the following actions to promote sleep:

- Prevent excessive light and noise from alarms and limit staff conversations.

- Evaluate the need for nursing care interruptions and allow an opportunity for uninterrupted sleep times during night and day.

- Explain environmental sounds and provide other information to reduce patient anxiety.

- Provide adequate pain relief and hypnotics and evaluate continuous analgesia to promote effective sleep.

\section{Accompaniment of patients on the me- chanical ventilator during the weaning pro- cess}

It is important for the intensive care nurse to accompany patients during the weaning process in order to lessen feelings of anxiety, stress and fear. Explanations of the weaning procedure, as well as what the patient can expect to feel, are very important. These should include the way in which the ventilator support will be decreased gradually thus allowing the patient to breathe more independently. In addition, patients should be told that they may feel a little short of breath and that they will be doing more of the breathing work. Encouraging patients to be active in managing their shortness of breath by demonstrating and teaching proper breathing techniques may help to empower patients so that the sensations produce less fear and anxiety. Reassuring the patient constantly is important while working through this weaning process.

\section{Improving emotional and spiritual com- fort}

Reducing emotions of stress, anxiety, panic and fear experienced by patients on the mechanical ventilator

The intensive care nurse needs to provide constant 
explanations and reassurance to patients who are connected to the mechanical ventilator. Knowledge of their condition seems to prepare them psychologically and give them a sense of control. It also helps them to stop worrying unduly and prepares them to initiate further enquiry. A daily routine also brings predictability to their environment, which allows them to prepare for the expected activity, thus providing them with a sense of control and ultimately reducing levels of anxiety and stress.

\section{Improving the communication process with patients on the ventilator}

The nurse should assess factors hindering the communication process e.g. language barriers, hearing problems or illiteracy and deal with these accordingly. Alphabet charts, picture boards, flash cards, writing using a pad and pen and/or mouthing words can be used to improve communication with the patient. A communication board containing simple words and illustrating basic needs can also be very useful, as it will help the patients to express their needs. The nurse must always talk to the patient and reassure them. Physical contact can assist in building a supportive relationship between the nurse and the patient on the ventilator.

\section{Reducing the noise levels in the intensive care environment}

Educating all personnel regarding reduced noise levels in the intensive care unit is important. They must avoid unnecessary noise and must consider resting time periods for the patients. Nurses must respond timeously to alarms and avoid the use of unnecessary alarms. Telephones should be answered promptly and telephone ringing tones must be set at an acceptable level to avoid unnecessary noise production.

\section{Reducing the use of continuous, harsh lighting in the intensive care unit}

The nurse should dim lights at night, as this will simulate a normal day-night cycle. Patients should also be placed next to windows if possible so that they are aware of day and night cycles. Ventilators, monitors and infusion pumps should be put on the night light option and the use of lights during the night must be kept minimal. Bed lighting should be used in order to avoid disturbances for other patients at night.

\section{Reducing anxiety experienced by patients at the unexpected sight of machinery and equipment}

Patients who were inadequately prepared for the intensive care unit often became anxious. It is thus advisable to provide patients who require the use of elective mechanical ventilation in the intensive care unit with information prior to the procedure. Adequate explanations regarding the use of equipment and machinery should be given in the case of an emergency intubation. This will reduce feelings of anxiety and panic in the patient.

\section{Reducing feelings experienced at the sight of other very sick patients}

The intensive care unit must be designed to limit the visual contact of patients to the suffering around them. Other sick patients present a reflection of their own helpless, failing bodies. A semi-circular design would be appropriate.

\section{Helping patients cope with feelings of helplessness and dependency}

Nurses must assure patients that the experience of weakness and fatigue is a normal response. Sufficient rest is essential and the nurse, therefore, performs most functions for them. This will reduce feelings of helplessness and dependency. However, if patients are strong enough to perform self-care activities they should be allowed to participate in these. Nurses can also assist patients to set small goals that are realistic and attainable and which will ultimately reduce feelings of helplessness.

\section{Accompaniment of patients who are on mechanical ventilation in order to assist them to work through their experiences of an awareness of their own mortality and spirituality}

Spiritual care and guidance are often difficult to render in the intensive care unit due to factors like the inability to maintain an effective communication system, noise, lack of privacy and the disease process. The intensive care nurse should, however, strive at all times to understand the experiences of patients and the meaning that illness and hospitalisation hold for them. She should support the patients unconditionally and show respect for their religious preference and practices. The nurse should also realise that the increased sense of 
gratitude and thankfulness towards God is important for patients and comes about mainly because they have realised their own mortality.

\section{LIMITATIONS}

The researcher identified the following limitations:

- Difficulty was encountered in securing interviews, as some patients did not remember much about the ventilatory process. Patients also had to comply with the selection criteria set out by the researcher, making the selection of participants even more difficult.

- The first interview was done in the intensive care unit but was abandoned as frequent interruptions by nurses, alarms and noise levels in the intensive care environment made this interview unsuccessful.

- Interviews in the general ward had to be done in a waiting room, or any empty room available for this purpose, as patients were seldom in private rooms that would have ensured privacy and curbed interruptions.

- $\quad$ The study was limited to one intensive care unit exclusively as the other urban hospital did not have suitable candidates that complied with the criteria for sampling set out by the researcher. Most of the patients that were on a ventilator never recovered successfully and those who did could not speak English or Afrikaans and could thus not be included in the study.

\section{RECOMMENDATIONS}

The following recommendations can be made with regard to the study.

\section{Nursing Research}

- $\quad$ This study only identified and explored the patients' perceptions of the intensive care unit environment and their experiences while connected to the ventilator and not those of the nurses caring for these patients. The inability to communicate effectively and to maintain a two-way communication system between the nurse and the patient was also an important aspect. Further research can be conducted to explore the nurses' experience of being unable to understand the patients' communication mode.
- $\quad$ Caring for patients on a ventilator can be demanding and further research needs to be done to identify the experiences of intensive care nurses while rendering care to these patients.

- Intensive care unit psychosis is a reality for patients in the intensive care unit and this can provide an area for further research, especially the effect of this syndrome on the patient after discharge from the hospital.

- $\quad$ Patients requiring long-term ventilatory support might experience the process of ventilation differently than those who require short-term ventilation. A comparative study regarding the differences in the experiences of patients requiring long-term versus short-term mechanical ventilatory support needs further research.

\section{Nursing Education}

- The formulated guidelines can be integrated into the in-service education programmes, which will assist the registered nurse to be more sensitive to the needs of patients on a mechanical ventilator.

\section{Patient Care}

- Debriefing sessions need to be conducted after the study or patients need to be referred to a professional (if required) to work through their experiences of being in the intensive care unit and being connected to the mechanical ventilator. Some patients expressed a need for this.

\section{Nursing Practice}

- $\quad$ The formulated guidelines need to be available to all nurses working in the intensive care units and need to be implemented where necessary.

\section{CONCLUSION}

Throughout the study the researcher realised that patients on a mechanical ventilator endured various physical, emotional and spiritual experiences as a result of their situation. They therefore need to be successfully accompanied by the nurses responsible for their care as their ability to overcome these experiences and to regain independence depends greatly on the assistance and support of the nurses. 
Through this study the researcher hopes that nurses will become more aware of the experiences of patients while connected to the ventilator. The study allows the 'voice' of the patient connected to a mechanical ventilator in the intensive care unit to be heard, a voice to which we as caregivers must pay attention.

\section{BIBLIOGRAPHY}

ASHURST, S 1997: Nursing care of the mechanically ventilated patient in ITU: 2. British Journal of Nursing, 6(9):474-485.

BERGBOM-ENGBERG, I \& HALJAMAE, H 1993: The communication process with ventilator patients in ICU. Intensive and Critical Care Nursing, 9:40-47.

BELITZ, J 1983: Minimizing the psychological complications of patients who require mechanical ventilation. British Journal of Nursing, 6(9):42-46.

BUCHER, L. \& MELANDER, S 1999: Critical Care Nursing. Philadelphia: WB Saunders Company.

BURNS, N \& GROVE, SK 1997: The practice of nursing research: conduct, critique \& utilization; $3^{\text {rd }}$ edition. Philadelphia: WB Saunders Company.

CORBO, BH 1995: Endotracheal intubation: adolescent ICU experiences. Critical Care Quarterly, 8(1):35-46.

CRESWELL, JW 1994: Research Design: Qualitative and Quantitative Approaches. Thousand Oaks: Sage Publications.

JABLONSKI, R 1994: Aspects of being mechanically ventilated. Qualitative Health Research, 4(2):186-207.

JOHNSON, MM \& SEXTON, DL 1990: Distress during mechanical ventilation: patients' perceptions. Critical Care Nurse, 10 (7):48-57.

JONES, C; GRIFFITHS, R; MACMILLIAN, R \& PALMER, T 1994: Psychological problems occurring after intensive care. British Journal of Intensive Care, 2:46-54.

KIDD, PS \& WAGNER, KD 1997: High Acuity Nursing. Stamford: Appleton \& Lange.

KNEBEL, AR 1991: Weaning from mechanical ventilation: current controversies. Heart and Lung, 20(4):321-331

KOTZÉ, WJ 1994: Fundamentals of Nursing. Unpublished Lecture Notes. University of Port Elizabeth.

KOTZÉ, WJ 1998: An Anthropological Nursing Science: Nursing Accompaniment Theory. Health SA Gesondheid, 3(2):3-14.

KREFTING, L 1991: Rigor in qualitative research; the assessment of trustworthiness. American Journal of Occupational Therapy, 45(3):214-222.

MORSE, JM \& FIELD, PA 1996: Nursing Research: the application of qualitative approaches. Chapman \& Hall.

RALEIGH, HH \& LEPCZYK, M \& ROWLEY, C 1990. Significant others benefit from pre-operative information. Journal of Ad- vanced Nursing, 15:941-945.

South African Society for Nursing Researchers 1996: Ethical standards for nurse researchers. Curationis, 19(1):74-75.

TOPT, M \& DAVIS, JE 1993: Critical care unit noise and rapid eye movement (REM) sleep. Heart and Lung, 22(3):252-258.

TURNER, JS; BRIGGS, SJ; SPRINGHORN, HE \& POTGIETER, PD 1990: Patients' recollections of intensive care experiences. Critical Care Medicine, 18(9):966-969.

TUTTY, JS; ROTHERY, MA \& GRINNEL, RM 1996: Qualitative Research for Social Workers: phases, steps and tasks. London: Allyn \& Bacon.

WELLER, BF \& WELLS, RJ. 1990: Baillière's Nurse's Dictionary. Philadelphia. WB Saunders Company. 